Research Article

\title{
Female Directors and Carbon Information Disclosure: Evidence from China
}

\author{
Ren He $\mathbb{D}^{1},{ }^{1,2}$ Mingdian Zhou $\mathbb{D}^{1},{ }^{1}$ Jing Liu $\mathbb{D}^{3},{ }^{3}$ and Qing Yang $\mathbb{D}^{2}$ \\ ${ }^{1}$ School of Maritime Economics and Management, Dalian Maritime University, Dalian 116026, China \\ ${ }^{2}$ School of Economics, Fudan University, Shanghai 200433, China \\ ${ }^{3}$ School of Management Engineering, Anhui Institute of Information Technology, Wuhu 241199, China
}

Correspondence should be addressed to Qing Yang; qyang@fudan.edu.cn

Received 4 June 2021; Accepted 14 August 2021; Published 2 September 2021

Academic Editor: Wei Zhang

Copyright $\odot 2021$ Ren He et al. This is an open access article distributed under the Creative Commons Attribution License, which permits unrestricted use, distribution, and reproduction in any medium, provided the original work is properly cited.

\begin{abstract}
In recent years, natural disasters and public health events caused by global warming have occurred frequently around the world. It has become a global consensus to actively respond to climate change. Firms are the main source of greenhouse gas emissions. The disclosure of carbon information is one of the most important ways for firms to respond to climate change. The effect of female directors on carbon information disclosure is still unclear. Considering that China is the largest country in greenhouse gas emissions and the social status of females in China is different from western countries, this paper explores the effect of female directors on carbon information disclosure by firms in China. Based on the sample of listed Chinese firms in high carbon industries during the period of 2012-2017, our empirical results show that female directors have a positive association with carbon information disclosure. In addition, we find that the power, educational level, and financial background of female directors have positive impacts on firms' carbon information disclosure. Our findings make a significant contribution to the ongoing debate on the role of female directors and provide new insights and policy implications for firms, regulators, and other stakeholders.
\end{abstract}

\section{Introduction}

In recent years, natural disasters and public health events caused by global warming such as floods, hurricanes, heat waves, forest fires, and outbreaks of infectious diseases have occurred frequently. Actively responding to climate change has become a global consensus. Greenhouse gases (GHG) emissions are the main causes of global warming, and firms, especially those in high carbon industries, are the main source of GHG emissions. Carbon information disclosure (CID), as an important way to reflect the behavior of firms in responding to climate change, has attracted increasing attention from researchers and practitioners. China, as the world's second largest economy, has become the largest carbon emitter, with its emissions of $\mathrm{CO}_{2}$ accounting for $28 \%$ of the total amount [1]. To reverse the situation, China made a significant US-China Joint Statement on Climate Change on 12 November 2014. In the statement, China plans to peak its carbon emissions no later than 2030, which leads
Chinese firms to a tremendous pressure of energy saving and emission reduction. Therefore, shareholders and other stakeholders intend to monitor and supervise firms' carbon emissions better, which is one of the biggest motivators of the steady growth of firms' CID in China in both quality and quantity in recent years [2].

Previous studies usually use a virtual variable or the index to measure firms' CID behavior. The virtual variable represents whether the firms disclose carbon information or whether they respond to the CDP questionnaire $[3,4]$. The index based on the content analysis method or the scores of CDP questionnaires represents the quality of firms' CID $[2,5]$. Unlike several countries such as France, Australia, Japan, the United States, and Canada that have implemented mandatory schemes that require disclosure of GHG emissions, China has not formulated mandatory CID requirements yet. The carbon information disclosed by firms in China can be regarded as voluntary [6]. Additionally, Chinese firms have a low rate of response to the CDP survey 
[7]. Based on the above, we adopt the content analysis to measure the CID behavior of firms. The research on the influencing factors of CID mainly focuses on the following aspects: (1) the firm characteristic factors, such as firm size [8-11], liability [12], and profitability [5]; (2) the corporate governance factors, such as board effectiveness [12], board independence [13], environmental committee [14-16], and ownership structure [2]; and (3) other factors, such as country [8], industry [2], regulations [17], and culture [18].

Previous studies have shown that the presence of female directors can increase firm's attention to social responsibility and environmental issues [19]. Moreover, it is generally recognized that the gender diversity of the board of directors plays an important role in promoting the environmentally friendly activities of firms [20]. Nevertheless, there are few studies on the effect of female directors on CID, and there are no unanimous conclusions $[16,21]$. Agency theory emphasizes that board members require managers to act in accordance with the interests of shareholders to reduce agency costs, and resource dependence theory suggests that board members need to bring resources to the organization. These two theories explain the necessity of female directors participating in corporate governance. Moreover, upper echelons theory considers that characteristics have an impact on human behavior which can help firms select board members. The following four characteristics of women make female directors excellent candidates to improve the level of firms' CID: interpersonal relationship, self-awareness, attitude to law and regulation, and attitude to work. The motivation of this study arises from the fact that so few research works focus on the role of women in CID. Considering that the culture and social status of women in China are different from those of western developed countries, it is necessary to investigate the influence of female directors on CID of firms in China. Our study also analyzes the influences of power, educational level, financial background, and legal background of female directors on firms' CID.

This study makes the following contributions to the existing literature. First, to the best of our knowledge, this study is the first to empirically investigate the impact of female directors' heterogeneous characteristics on firms' CID. Existing research on the determinants of the firm's CID usually regards female directors as homogeneous, which leads to inconsistent conclusions to a certain extent. This study finds that female directors on boards have a significantly positive effect on firms' CID, and the power, educational level, and financial background of female directors have positive impacts on firms' CID.

Second, this study uses text analysis based on annual and social responsibility reports of Chinese firms to analyze CID quality. Existing research has explored the relationship between female director ratio and CID of firms based on CDP data. Considering that CID is voluntary in China and Chinese firms have a low rate of response to the CDP survey [7], annual and social responsibility reports are the main and important accessible source of carbon information for stakeholders of Chinese firms. This study calculates an index using text analysis based on carbon-related information in Chinese firms' annual and social responsibility reports.
Third, focusing on the Chinese context, this study can provide empirical evidence on female directors' role in firms' CID behavior in eastern developing countries. European countries such as Norway, Netherlands, and Italy have mandated quotas for women on board. Even in western countries where there are no mandatory requirements, the proportion of female directors is relatively high [16]. However, in eastern countries such as China, there are no mandated quotas for women on board, and women's social status is relatively low. In ancient Chinese feudal society, women are only "family persons" with very low social society [22]. In modern Chinese society, women's social status has been relatively improved, and there is a loud slogan that "women can hold up half the sky." However, Chinese traditional culture such as Confucianism still has a negative influence on the board gender diversity of firms in China [23]. In the context of China, this study can better investigate the influence of female directors on firms' CID behavior in eastern countries. Furthermore, the findings based on the context of China can add value to the theoretical completeness of previous research on female directors and CID based on western developed countries.

The remainder of this paper is structured as follows: Section 2 reviews the existing relevant literature. Section 3 presents the theoretical analysis and research assumptions. Section 4 describes the selection of samples and data and the research methods used in this paper. Section 5 shows our empirical results and conducts the robustness tests. Section 6 discusses the research conclusions.

\section{Literature Review}

\subsection{The Influencing Factors of Carbon Information Disclosure.} Over the decades, global warming has aroused widespread concern all over the world, and the GHG emissions are mainly attributed to firms. In this context, the external pressure on firms to disclose carbon information is increasing, especially for firms in carbon-intensive industries [24], in which the carbon information transparency is enhanced compared to less carbon-intensive industries $[25,26]$. Additionally, environmental NGOs, governments, and investors claim that firms should disclose information related to their GHG emissions [27]. Matsumura et al. believe that the cost of not disclosing carbon information is very high, which will have a negative impact on the value of firms [28]. Therefore, most firms tend to voluntarily disclose carbon information to enhance their environmentally friendly image in the eyes of the stakeholders [29]. Some firms are gradually developing sectors and systems for the assessment, accounting, reporting, and management of GHG emissions and their related impacts [30].

The existing research on the influencing factors of CID mainly focuses on three aspects: The first aspect is firm characteristics. Prior studies suggest that the firm with a larger size is more likely to disclose high quality carbon information [8-11]. Ben-Amar and Mcilkenny find a negative association between the firm's liability level and voluntary disclosure [12]. Faisal et al. report a positive association between the profitability of the firm and CID 
quality [5]. The second aspect is corporate governance. Board effectiveness is an important factor affecting the tendency and quality of CID [12]. Liao et al. argue that the level of CID is higher for firms, of which the board is more independent [13]. Recent empirical evidence shows that the establishment of an environmental committee under the board of directors contributes to the disclosure of carbon information [14-16]. Peng et al. perform an empirical analysis of Chinese firms and show that the more decentralized the ownership is, the more likely the firm is to disclose carbon information [2]. The third aspect includes other factors. There is evidence showing that country, industry, regulations, and culture also affect firms' CID. Freeman and Jaggi find that firms registered in countries that ratified the Kyoto Protocol are more likely to disclose GHG emissions information [8]. Firms in high-emission industries are more likely to disclose more carbon information [2]. Environmental regulations and legal sources are essential to firms' CID behavior [17]. He et al. find that traditional Chinese culture such as Confucianism can also have a positive effect on the quality of firms' CID in China [18].

Existing literature on CID shows that the board of directors plays an important role. Therefore, the effectiveness of boards will still be the core of research on corporate governance [31]. On the basis of principal-agent theory and the theory of resource dependence, the board of directors mainly has the two functions of supervision and suggestion in the firm [32]; that is, the board not only supervises the behavior of management on behalf of shareholders [33], but also relies on its own professional knowledge to provide advice and consulting services for the company [34]. According to the existing literature, several board characteristics that affect the effectiveness of corporate governance and CID include board size and independence, board diversity, and CEO duality. These studies suggest that the board that is larger, independent [13], and diverse $[12,13,35]$ can positively influence firms' CID. The diversity of the board of directors plays an important part in improving corporate governance [36], and the impact of gender diversity on corporate governance and CID is receiving increasing attention in recent years.

2.2. The Outcomes of Board Gender Diversity. Previous research has explored the outcomes of board gender diversity. The research mainly covers three aspects. The first aspect is the effect of board gender diversity on firm performance. Existing studies have inconsistent evidence on the effect of female directors on firm performance. Post and Byron find that female directors have a positive association with firms' accounting returns, especially in countries where shareholder protections are strong [37]. The results of other studies also show that board gender diversity could improve firm value or financial performance [38-40]. However, Joecks et al. find that the link between gender diversity and firm performance follows a U-shape [41]. Abdullah et al. find that female directors can create value for some firms and decrease it for others [42]. The absence of a significant relationship between gender diversity and firm financial performance is also supported by empirical evidence [43].
The second aspect is the effect of board gender diversity on corporate social responsibility (CSR). Most studies' results show that board gender diversity has a positive effect on CSR. For example, firms with a higher percentage of women in boardrooms have better CSR disclosure [44, 45], higher CSR ratings [19], and stronger CSR performance [46, 47]. Women on the board of directors could increase the firm's sense of responsibility to society [48], and they care about human rights and contribute to the improvement of corporate governance [49]. However, Manita et al. find that there is no significant relationship between board gender diversity and ESG disclosure [20]. Studies have also shown that CSR is a diverse and complex concept, and female directors are only related to some specific CSR dimensions, such as environmental aspects [50].

The third aspect is the effect of board gender diversity on environmental issues. Environmental concerns are also a nonignorable part of gender diversity research. Studies have shown that female directors can improve environmental corporate social responsibility [51]. Empirical research shows that female directors help reduce firms' environmental violations [52]. As an integral part of corporate environmental social responsibility disclosure, GHG related disclosure has walked onto the stage. There are few studies separately investigating the association between GHG related disclosure and female board representation [16], and the existing studies show inconclusive results. For example, the research result of Kilic and Kuzey shows that there is an insignificant association between board gender diversity and carbon emission disclosure in Turkey [21]. However, Hollindale et al. find that firms with multiple female directors in Australia make higher quality GHG emissions related disclosures [16]. Liao et al. find a significant positive association between gender diversity and GHG information disclosure of firms in the United Kingdom [13]. More precisely, BenAmar et al. find that female boardroom participation in Canadian firms is positively related to the voluntary disclosure of carbon information and further find that gender diversity on boards of directors can only have an impact on the disclosure of carbon information when there are more than two women on board [53].

\section{Theory and Hypotheses Development}

3.1. Female Directors and Carbon Information Disclosure. When studying gender diversity and environmental concerns, there are two questions worth considering. First, why do female directors need to do this? Agency theory provides an internal motivation to explain this problem, caused by the agency conflict between managers and shareholders [54]. Managers usually focus on increasing self-interest, which in turn damages the interests of shareholders [47]. Therefore, it is a reasonable demand for board members to be supervisory and ask managers to behave on behalf of the shareholders' best interests, which is protected by law [12]. Hence, the supervisory function of female directors is one of the effective means to resolve agency conflicts and improve corporate governance efficiency [13, 43, 49, 55, 56]. Resource dependence theory provides an external motivation to 
answer this question. It advocates that board members need to bring resources to their organizations [57]. These resources can be knowledge, skills and experiences [58], human resources [49], and interpersonal relationships and values [45]. Therefore, female directors can play an advisory role in the firm, providing suggestions and resources that enable the firm to develop steadily.

The second question is, why can female directors do this? Upper echelons theory suggests that top executives' knowledge, experience, values, and personalities have an influence on their process of decision-making [59]. This theory gives a better understanding of what kind of board members should be chosen and can help firms solve environmental problems. Compared to men, there are several aspects that affect female directors' decision-making: (1) interpersonal communication: they are democratic, cooperative, caring (willing to help, getting along well, kind, sympathetic, responding to the needs of others, not selfcentered) $[53,60]$; (2) self-awareness: they have high moral standards and value quality of life rather than material success (full of social responsibility, caring about the environment, caring about health, having environmental sensitivity) [50, 61, 62]; (3) attitude to law and regulation: they are cautious (risk aversion, abiding by the law) $[12,56,63,64]) ;(4)$ attitude towards work: they are dedicated and possess high skills (hardworking, industrious) $[65,66]$. Thus, female directors have a different cognitive frame to a board on account of different experiences and value orientation, and gender diverse boards may tend to consider, discuss, and integrate information more deeply and carefully than homogeneous groups [37]. Female directors could enhance communication with key stakeholders who care about environmental issues [67]. Female directors' high sensitivity to people and surroundings makes them care more about environmental issues. Since female directors are more likely to be more concerned about loss of reputation and litigation [68], they have a nature of abiding by laws and regulations. Most importantly, they are dedicated to what they are doing. Finally, due to the above characteristics of female directors, they have a propensity to make environment-friendly decisions, which will affect the firm's CID decisions. Their supervisory and advisory functions and the resources they can bring to the organization improve the firm's governance quality and thus affect the firm's CID quality. Therefore, we formulate the following hypothesis.

Hypothesis 1. Female directors are positively associated with firms' carbon information disclosure.

\subsection{The Characteristics of Female Directors and Carbon In-} formation Disclosure. Women face complex and various challenges in the process of accessing power [60]. It is feasible that women who can conquer so many obstacles and break through a mass of barriers must obtain outstanding abilities to find their way out in the male-dominated territory [69]. In China, female directors account for only around $11 \%$ of seats in recent years $[47,70]$. In addition, there are no mandated quotas for women on board in China.
Based on the above, we can conclude that, in this maledominated board structure, when female directors are presidents or CEOs, female directors can be treated as a symbol of competency and power to the board. Van Staveren suggests that more women at the top position can effectively avoid the occurrence of banking crisis [63]. Female directors can also improve the efficiency of risk management in $R \& D$ investments [71]. Based on the above analysis, when female directors have power, it is reasonable to presume that they will use this power to make firms pay attention to environmental issues such as CID. Therefore, we formulate the following hypothesis.

Hypothesis 2. The power of female directors is positively associated with firms' carbon information disclosure.

According to Hitt and Tyler, the manager's view of the world, philosophy, values, and even ability of cognizance can be influenced by educational level [72]. Vives and Gadenne et al. propose that having a higher level of education generates a greater level of commitment to CSR activities $[73,74]$. Managers with high level education usually care more about environmental issues and may apply their knowledge to put pressure on firms to deal with environmental violation and take action to correct bad behavior [75]. Beji et al. find that the educational level of directors is positively and significantly associated with CSR and environmental performance of firms [49]. As China's carbon emission policy becomes stricter, carbon management and CID will be one of the most important environmental issues for Chinese firms. Based on the above analysis, we argue that female directors with higher educational level will have more environmental consciousness and are more likely to make requests to disclose more carbon information. Therefore, we formulate the following hypothesis.

Hypothesis 3. The educational level of female directors is positively associated with firms' carbon information disclosure.

According to the studies of Hambrick and Mason [59] and O'Fallon and Butterfield [76], it is difficult for people's decision-making not to be influenced by vocational education. Previous research shows that there is a positive relationship between business education and CSR [77]. Panapanaan et al. propose that business studies have a link with ethics, CSR, sustainability, and, consequently, boost ethics in a firm [78]. Most directors with financial background have received business education and they would care more about CSR and sustainability issues than directors with other expertise. Moreover, directors with financial background can better understand the consequences of financial reporting decisions. As an important part of financial reporting, carbon information is concerned by shareholders and CID is related to firms' value [79], capital cost [80], and financial performance [81]. Directors with financial background would make firms disclose more carbon information, and female directors with financial background are expected to have more influence on CID than male directors with financial background. From recent literatures, we can discover that female directors can affect 
many aspects of the firm's financial status. For example, research shows that female board representation with business expertise and audit committee membership can strongly improve earnings management [82]. Based on the above analysis, we propose that female directors with financial expertise are an important factor for ensuring the quality of corporate governance. It is also sensible that female directors pay more attention to the boundary between corporate performance and environmental protection, and those with financial background can better balance them. Therefore, we formulate the following hypothesis.

Hypothesis 4. The financial background of female directors is positively associated with carbon information disclosure.

In addition to the financial background, what cannot be ignored is that legal awareness can also exert an influence on human's behavior. Most directors and managers with a legal background have received legal degrees. Prior research has demonstrated that individuals with legal degrees exhibit distinctive decision-making patterns compared to those without legal degrees [83]. Barker and Mueller argue that an executive with legal degrees tends to be more conservative in business activities [84]. Previous research finds that managers with legal background tend to spend less on R\&D [84] and guide down earnings forecasts due to a greater sensitivity to litigation risk [85]. Considering that they usually prefer risk mitigation, we expect that directors with a legal background will care more about the potential costs of CID. Firms tend to disclose less carbon information because directors with legal background exhibit greater risk aversion. However, female directors will have a positive impact on the firms' CID based on the analysis of Hypothesis 1 . We predict that the positive impact of female directors on CID may be offset by their own legal background. Therefore, we formulate the following hypothesis.

Hypothesis 5. The legal background of female directors is not associated with carbon information disclosure.

\section{Research Design}

4.1. Samples. Firms' CID started relatively late in China compared with firms in developed countries. At present, Chinese government has not issued a mandatory CID policy yet; Chinese firms' CID is voluntary. Firms in high carbon industries are more sensitive to climate change risks than other firms, and they are more likely to report more carbon information to reduce compliance costs at an early stage. Many studies conclude that firms in high carbon industries disclose more carbon information than firms in low carbon industries [2, 12, 53]. The Ministry of Environmental Protection of China has identified 16 industries as heavily polluting industries, namely, thermal power generation, steel, cement, electrolytic aluminium, coal, metallurgy, chemicals, petrochemicals, building material, paper, brewing, pharmaceuticals, fermentation, textile, leather, and mining. The heavily polluting industries mostly overlap with the top 13 GHG emissions industries [2]. We could find that most of the heavily polluting industries are also high carbon industries.
Based on the above, the initial samples of our study include all A-share listed firms in high carbon industries, which include heavily polluting industries and the top 13 GHG emissions industries in China between the years 2012 and 2017. Firms with missing data and marked with ST and ${ }^{*} \mathrm{ST}$ are excluded from samples. To better investigate the trends in the CID quality of firms in high carbon industries in China between the years 2012 and 2017, balanced panel data were used in this study. The final samples include 541 A-share listed firms in high carbon industries in China. The distribution of industries for sample firms is shown in Table 1 . The carbon information is derived from firms' annual reports, social responsibility reports, and sustainable development reports. The other data are from the CSMAR database and the RESSET database.

\subsection{Measures}

4.2.1. Carbon Information Disclosure. In this research, we adopt two variables as the dependent variables to measure the firms' CID. One is a dummy variable (CID_DUM) that is equal to 1 if the firm discloses carbon information and 0 otherwise. The other is the quality of the firm's CID (CID_QUALITY), measured by content analysis. Content analysis was adopted in the same way as Peng et al.; it was used in their research for evaluating the quality of CID [2]. Carbon information disclosed by firms is identified by eight items $\left(I_{1}\right.$ to $\left.I_{8}\right)$ which strictly refer to CDP's questionnaire. The detailed information of the eight items is shown in Table 2. The specific scoring rules are shown in Table 3.

Each firm is assigned a score of CID quality based on the following equation:

$$
\text { Score }(\mathrm{CID})_{j}=\sum_{i=1}^{8} \operatorname{Score}\left(I_{j}^{i}\right) .
$$

In equation (1), Score (CID) ${ }_{j}$ is the total score of CID for firm $j$, representing the quality of CID of firm $j$, and Score $\left(I_{j}^{i}\right)$ refers to firm $j$ 's score on item $i$.

4.2.2. Female Directors. The independent variable is female directors. Based on the previous research, the proportion of female directors (FEM_RAT) is utilized in our research $[13,53]$. Besides, according to Hollindale et al.'s study, we also adopt a dummy variable (FEM_DUM) that is coded 1 if the firms have at least one female director and 0 otherwise [16]. To further explore the mechanism of the effect of female directors on CID, four variables representing different characteristics of female directors were selected, namely, whether the female directors are presidents or CEOs (POWER) and female directors' educational background (EDUC), financial background (FINAN), and legal background (LEGAL).

4.2.3. Controls. To control for the firm characteristics that may drive the examined relationship, we introduce ten control variables into our regression model. 
TABLE 1: Industry distribution of the sample firms.

\begin{tabular}{lcc}
\hline Industries & $N$ & Percentage \\
\hline Production and supply of electric power, heat, gas, and water & 66 & 12.20 \\
Steel, electrolytic aluminium, metallurgy & 8.87 \\
Cement, building material & 48 & 45 \\
Coal, mining & 54 & 9.32 \\
Chemicals, petrochemicals & 117 & 21.63 \\
Papermaking and paper products & 14 \\
Brewing, fermentation & 40 \\
Pharmaceuticals & 2.59 \\
Textile & 7.39 \\
Leather, furs, and related products & 102 \\
Agro-food processing & 22 \\
Special equipment, transportation equipment, communications, and related equipment manufacturing & 4.07 \\
Total & 5 & 25 \\
\end{tabular}

TABLE 2: Eight items of CID.

\begin{tabular}{lc}
\hline Item & Detailed information \\
\hline$I_{1}$ & Targets and results of emission reduction \\
$I_{2}$ & Method of measuring carbon emission \\
$I_{3}$ & Scope 1 emission data: direct greenhouse gas emissions \\
$I_{4}$ & Scope 2 emission data: indirect greenhouse gas emissions of energy \\
$I_{5}$ & Scope 3 emission data: other indirect greenhouse gas emissions \\
$I_{6}$ & Energy consumption of total operation in the reporting year \\
$I_{7}$ & Emissions trading \\
$I_{8}$ & Other carbon-related information \\
\hline
\end{tabular}

The items of CID are adopted from Peng et al. [2].

TABLE 3: Scoring rules of eight items of CID.

\begin{tabular}{|c|c|c|}
\hline & Score & Scoring rules \\
\hline$I_{1}$ & & No information scores 0 , general nonquantitative information scores 1 , and some quantitative information scores 2 . For $I_{1}$, \\
\hline$I_{2}$ & & detailed quantitative information scores 3 (e.g., the time, quantitative targets, completeness of targets). For $I_{2}$, detailed \\
\hline$I_{3}$ & $0,1,2,3$ & measuring process scores 3 (e.g., the method used, the formula used, and the parameter applied). For $I_{3}, I_{4}$, and $I_{5}$, detailed \\
\hline$I_{4}$ &, 3 & quantitative information scores 3 (e.g., the boundaries used for scope 1, 2, or 3 greenhouse gas inventory and emissions \\
\hline $\begin{array}{l}I_{5} \\
I_{6}\end{array}$ & & $\begin{array}{l}\text { figures in metric tons of } \mathrm{CO}_{2} \text { ). For } I_{6} \text {, detailed quantitative information scores } 3 \text { (e.g., fuel consumption data in tons and per } \\
\text { value). }\end{array}$ \\
\hline $\begin{array}{l}I_{7} \\
I_{8}\end{array}$ & $0,1,2,3$ & $\begin{array}{c}\text { No information scores } 0 \text {, general nonmonetary information scores } 1 \text {, other concrete nonmonetary information scores } 2 \text {, and } \\
\text { monetary information records } 3 \text {. }\end{array}$ \\
\hline
\end{tabular}

The scoring rules of eight items of CID are adopted from Peng et al. [2].

(1) Size. Larger firms are more vulnerable to public attention than smaller ones. Investors have higher information quality requirements for larger firms. Large firms will disclose carbon information to improve their image. Prior research indicates that a larger size of the firm is associated with a better CID quality [8, 13]. Accordingly, we control for firm size, as measured by the natural logarithm of the total assets.

(2) Leverage. Financial leverage is an important indicator that not only reflects the degree of use of firms' external funds, but also reflects the firms' financial risk. Highly leveraged firms are under greater financial pressure and may disclose less high quality carbon information. Previous studies have shown a negative effect of financial leverage on firms' CID $[2,7,12]$. However, some studies have also shown that financial leverage has no significant impact on the disclosure of firms' environmental information [86].
(3) Profitability. Firms with high profitability have sufficient funds to ensure that they could bear the costs associated with CID. On the contrary, the disclosure of carbon information is beneficial to the establishment of a good corporate image and, in turn, attracts more investors. Less profitable firms are limited by the lack of their own resources and are unlikely to take the initiative to disclose relevant information. Some studies have found a positive correlation between profitability and CID quality [5, 12, 87, 88]. Consequently, profitability in our study measured by return on assets (ROA) was controlled. However, some studies have also shown that there is no significant correlation between firm profitability and CID $[8,24]$.

(4) Ownership Concentration. Previous studies have shown that ownership concentration may have an influence on firms' CID, but the relationship between ownership 
concentration and CID quality is unclear. Berthelot and Robert find that firms with widely held ownership voluntarily disclose more climate change information [14]. However, Li et al. found that there is no significant relationship between the proportion of first shareholders and CID [7]. In our study, ownership concentration (OC) was measured by the shareholding ratio of the top 10 shareholders.

(5) Independence of the Board. The independence of the board of directors is an important guarantee for it to perform its supervisory functions. More independent directors can urge firms to better fulfill the obligation of environmental information disclosure. Previous studies have indicated that firms with a larger proportion of independent directors in the board are more likely to make comprehensive financial information disclosure [89] and to disclose carbon information [13]. Therefore, the independence of the board may have a positive impact on CID. The percentage of independent directors on the board (IND) measures the independence of the board in our study.

(6) Duality. The president has decision-making powers and supervision powers, and CEO is the executor of board decisions and is supervised by the board. The presence of the same person holding the position of president and CEO could positively affect corporate social responsibility [19]. Alternatively, the decision-making, oversight, and executive functions being concentrated on a single individual will weaken the supervision power. Prior research has shown that there exists a negative association between duality and CID [7]. We use a dummy variable (DUAL) to measure the duality.

(7) Firm Value. Tobin's $q$ measured by the ratio of market value to asset replacement cost could represent the firm value. Firms with low firm value have a stronger willingness to disclose environmental information to gain the favor of investors and the government. Previous studies indicated that there is a significant negative correlation between firm value and CID [15]. We use Tobin's $q$ (TOBINQ) as the proxy of firm value.
(8) Nature. Previous studies have found that the state-owned nature of firms has a significant positive impact on CID [7]. In China, firms are mainly divided into state-owned enterprises (SOEs) and non-state-owned enterprises, with the former having a strong executive power in responding to national policies. At present, the Chinese government has been advocating a low carbon economy. Therefore, stateowned enterprises are more active than non-state-owned enterprises in energy conservation, emission reduction, and CID. However, some studies found that the influence of the state-owned nature of the firm on CID is not significant $[4,5]$. A dummy variable (NATURE) was introduced in our study: 1 for SOEs, 0 for others.

(9) Listing Age. The listing age of a firm has a significant positive influence on a firm's environmental performance [9]. The number of years a firm has been publicly traded is positively associated with the quality of firms' CID [2]. However, there are studies finding that a firm's listing age is not significantly related to the quality of CID [7]. Accordingly, the listing age of the firm (AGE) is introduced in our study as a control variable.

(10) Audit Firm. According to Dunn and Mayhew [90], a more professional accounting firm will provide more professional knowledge and advice to the clients in handling the disclosure related issues [90]. In addition, firms are willing to hire highly specialized audit firms, which is an obvious signal of the firms to disclosure high quality information. Based on the above, we expect that listed firms that hire the big four accounting firms are more likely to disclose carbon information and the quality of CID is higher. A dummy variable (AUDF) was introduced in our study: it equals 1 if a firm hires the big four accounting firms and 0 otherwise. The summary of the variable definitions is shown in Table 4.

4.3. Model. To test the hypotheses of this study, the following multiple regression models were constructed:

$$
\begin{aligned}
\text { CID_DUM } & =\alpha+\beta \text { Female }_{i, t}+\gamma \text { Controls }_{i, t}+\varepsilon_{i, t}, \\
\text { CID_QUALITY } & =\alpha+\beta \text { Female }_{i, t}+\gamma \text { Controls }_{i, t}+\varepsilon_{i, t}, \\
\text { CID_DUM } & =\alpha+\beta_{1} \text { Power }_{i, t}+\beta_{2} \text { Educ }_{i, t}+\beta_{3} \text { Finan }_{i, t}+\beta_{4} \text { Legal }_{i, t}+\gamma \text { Controls }_{i, t}+\varepsilon_{i, t}, \\
\text { CID_QUALITY } & =\alpha+\beta_{1} \text { Power }_{i, t}+\beta_{2} \text { Educ }_{i, t}+\beta_{3} \text { Finan }_{i, t}+\beta_{4} \text { Legal }_{i, t}+\gamma \text { Controls }_{i, t}+\varepsilon_{i, t},
\end{aligned}
$$

where Female was measured by two alternative variables: the dichotomous indicator variable (FEM_DUM) and the percentage of female directors (FEM_RAT). The hypotheses were tested using multiple regression, with each of the two independent variables regressed on the dependent variable, respectively. In models (2) and (4), CID_DUM is a dichotomous variable, which represents the firm's decision on whether to disclose carbon information. Hence, we 
TABle 4: Variable definitions.

\begin{tabular}{|c|c|}
\hline Variables & Measurement \\
\hline CID_DUM & A dummy variable that is equal to 1 if the firm makes carbon information disclosure and 0 otherwise \\
\hline CID_QUALITY & The scores of carbon information disclosure quality determined by content analysis \\
\hline FEM_DUM & A dummy variable that is equal to 1 if there is at least one female director on board and 0 otherwise \\
\hline FEM_RAT & The ratio of the number of female directors to the total number of board members \\
\hline POWER & A dummy variable that is equal to 1 if there is a female director as president or CEO and 0 otherwise \\
\hline EDUC & A dummy variable that is equal to 1 if there is at least one female director with a master's degree or above and 0 otherwise \\
\hline FINAN & A dummy variable that is equal to 1 if there is at least one female director with a financial background and 0 otherwise \\
\hline LEGAL & A dummy variable that is equal to 1 if there is at least one female director with a legal background and 0 otherwise \\
\hline SIZE & The natural logarithm of total assets \\
\hline LEV & The ratio of total debt to total assets \\
\hline ROA & Return divided by total assets \\
\hline OC & The percentage of total ordinary shares owned by the top ten shareholders \\
\hline IND & The percentage of independent directors on the board \\
\hline DUAL & A dummy variable that equals 1 if the positions of the president and CEO are held by the same person and 0 otherwise \\
\hline TOBINQ & The ratio of the market value to the replacement cost of the total assets of the firm \\
\hline NATURE & A dummy variable that is equal to 1 if the nature of the firm is state-owned and 0 otherwise \\
\hline AGE & The natural logarithm of the listing years of firms \\
\hline AUDF & A dummy variable that is equal to 1 if the audit firms hired by the firm are the big four accounting firms and 0 otherwise \\
\hline
\end{tabular}

performed probit model regression to examine the effect of female directors and their characteristics on the firms' CID. In models (3) and (5), CID_QUALITY represents the quality of firms' CID. We utilized ordinary least squares (OLS) analysis to examine the influence of female directors and their different characteristics on the quality of CID. The characteristics of female directors selected for this study include female directors' power, educational background, financial background, and legal background.

\section{Results}

5.1. Descriptive Statistics and Correlation Analysis. Table 5 provides the distribution of the number and percentage of sample firms that disclosed carbon information and had female directors by year. The number of sample firms disclosing carbon information and having female directors showed an overall growth trend between 2012 and 2017. On average, $49.60 \%$ of the sample firms voluntarily disclosed carbon information. In addition, $70.79 \%$ of the sample firms have female directors.

Descriptive statistics of the variables are shown in $\mathrm{Ta}$ ble 6 . The results show that there exists a big gap in the quality of CID among firms. The mean of FEM_RAT is 0.137 , revealing that women only account for about $14 \%$ of the boards of sample firms, which is a relatively low level. The mean of FEM_DUM is 0.708 , which shows that about $71 \%$ of the sample firms have women on the board. Around half of the female directors in sample firms have a master's degree or higher degrees, and about $41 \%$ of female directors have financial background. The proportion of female directors having power or legal background is relatively low, only $20.4 \%$ and $10.9 \%$, respectively. The mean of ROA is $4.78 \%$, and the maximum and minimum values of ROA are $51.66 \%$ and $-39.92 \%$, respectively, which illustrates that the rate of return on total assets among firms has a great difference. The minimum and maximum of OC are $1.3 \%$ and $98.6 \%$, respectively, which means that the ownership concentration of sample firms has an obvious difference. The mean value of DUAL is 0.222 , which means that the same person holds the position of president and CEO in $22.2 \%$ of the sample firms. The mean of NATURE is 0.473 , which indicates that there is no significant difference between the proportion of stateowned enterprises and non-state-owned enterprises in the sample. The mean of AUDF is 0.065 , which implies that merely $6.5 \%$ of the sample firms employed the big four accounting firms.

Table 7 shows the Pearson correlation and variance inflation factor (VIF) for dependent, independent, and control variables. The correlation coefficients for CID_DUM, FEM_DUM, and FEM_RAT are positive and significant, supporting Hypothesis 1. The correlation coefficients for CID_DUM, EDUC, and FINAN are positive and significant, supporting Hypotheses 3 and 4. The relatively low correlation coefficients between independent and control variables and their VIF suggest that there is no multicollinearity problem in the four models of this study.

5.2. Multiple Regression Results. We tested the relation between female directors and firms' CID decisions utilizing probit regression. The results in columns 1 and 2 of Table 8 (model (2)) show that the coefficients of FEM_DUM and FEM_RAT are positive and significant at the $1 \%$ level. These results indicate that firms with female directors are more likely to disclose carbon information, and the increasing of the representation of women on board could promote firms' CID decisions and attention to climate change issues. These results support Hypothesis 1. Our findings are consistent with prior research based on British and Canadian firms which shows that there is a positive association between board gender diversity and firm's response to CDP questionnaire $[13,53]$. As for the control variable, firm size and hiring the big four accounting firms have a significant positive effect on firms' CID. Meanwhile, state-owned enterprises are more likely to disclose carbon information to 
TABLE 5: The percentage of firms disclosing carbon information and having female directors.

\begin{tabular}{|c|c|c|c|c|c|}
\hline \multirow[t]{2}{*}{ Year } & \multirow[t]{2}{*}{ Total } & \multicolumn{2}{|c|}{$\begin{array}{l}\text { Firms disclosing carbon } \\
\text { information }\end{array}$} & \multicolumn{2}{|c|}{ Firms with female directors } \\
\hline & & $N$ & $\%$ & $N$ & $\%$ \\
\hline 2012 & 541 & 256 & 47.32 & 367 & 67.84 \\
\hline 2013 & 541 & 257 & 47.50 & 375 & 69.32 \\
\hline 2014 & 541 & 258 & 47.69 & 380 & 70.24 \\
\hline 2015 & 541 & 267 & 49.35 & 387 & 71.53 \\
\hline 2016 & 541 & 287 & 53.05 & 395 & 73.01 \\
\hline 2017 & 541 & 285 & 52.68 & 394 & 72.83 \\
\hline Total & 3246 & 1610 & 49.60 & 2298 & 70.79 \\
\hline
\end{tabular}

TABLE 6: Descriptive statistics of variables.

\begin{tabular}{|c|c|c|c|c|c|}
\hline Variable & $N$ & Mean & $\mathrm{SD}$ & Min & Max \\
\hline CID_DUM & 3246 & 0.496 & 0.500 & 0 & 1 \\
\hline CID_QUALITY & 3246 & 1.380 & 2.158 & 0 & 16 \\
\hline FEM_DUM & 3246 & 0.708 & 0.455 & 0 & 1 \\
\hline FEM_RAT & 3246 & 0.137 & 0.126 & 0 & 0.857 \\
\hline POWER & 3246 & 0.204 & 0.403 & 0 & 1 \\
\hline EDUC & 3246 & 0.464 & 0.499 & 0 & 1 \\
\hline FINAN & 3246 & 0.413 & 0.492 & 0 & 1 \\
\hline LEGAL & 3246 & 0.109 & 0.312 & 0 & 1 \\
\hline SIZE & 3246 & 22.41 & 1.294 & 19.08 & 28.51 \\
\hline LEV & 3246 & 0.414 & 0.203 & 0.014 & 1.059 \\
\hline $\mathrm{ROA}$ & 3246 & 4.782 & 5.820 & -39.92 & 51.66 \\
\hline OC & 3246 & 0.577 & 0.154 & 0.013 & 0.986 \\
\hline IND & 3246 & 0.370 & 0.053 & 0.182 & 0.667 \\
\hline DUAL & 3246 & 0.222 & 0.416 & 0 & 1 \\
\hline TOBINQ & 3246 & 1.993 & 1.698 & 0.123 & 21.02 \\
\hline NATURE & 3246 & 0.473 & 0.499 & 0 & 1 \\
\hline AGE & 3246 & 2.308 & 0.667 & 0 & 3.296 \\
\hline AUDF & 3246 & 0.065 & 0.247 & 0 & 1 \\
\hline
\end{tabular}

the public than non-state-owned enterprises because stateowned enterprises have always been active responders to government policies in China. We also find that both leverage and listing age are significantly negatively related to voluntary disclosure of carbon information.

We also examine the relationship between female directors and CID quality using ordinary least squares (OLS) regression, and the regression results are as shown in columns (3) and (4) of Table 8 (model (3)). The coefficient of FEM_DUM is 0.337 , which is significant at the $1 \%$ level. This result suggests that firms with women on board are more likely to disclose high quality carbon information compared with firms whose board members are all male. The coefficient of FEM_RAT is 1.565 , which is significant at the $1 \%$ level, implying that the higher the proportion of female directors in the firm, the higher the quality of the firm's CID. Therefore, Hypothesis 1 is supported. Meanwhile, stateowned enterprises and firms with larger size, lower leverage, more independent boards, separation of president and CEO positions, higher firm value, and the big four accounting firms hired are more likely to disclose higher quality carbon information.

The regression results of models (4) and (5) are shown in columns (1) and (2) of Table 9, respectively. The coefficient of POWER is positive and statistically significant at the $1 \%$ level for regressions in model 4 and model 5, meaning that female directors who also hold the position of president or CEO can promote the firms' CID. The finding supports Hypothesis 2. The coefficients for EDUC are positive and significant at the $1 \%$ level, which support Hypothesis 3 that highly educated female directors are positively associated with firms' CID compared with female directors with lower levels of education. The regression result shows that female directors' financial background has a positively impact on firms' CID decisions, which supports Hypothesis 4. However, we also find that the effect of female directors' financial background on firms' CID quality is limited. Moreover, female directors' legal background has no significant impact on firms' CID decisions and CID quality. Thus, Hypothesis 5 is supported.

\subsection{Robustness Tests}

5.3.1. Endogeneity. According to previous research, endogeneity problems could exist for board gender diversity. In our study, the relationship between female directors and firms' CID may be driven by omitted unobserved factors or by reverse causality. Some omitted unobservable firm characteristics, such as firm culture, could be linked to both female directors and firms' CID. The literature generally deals with unobservable variables by using a fixed effect 


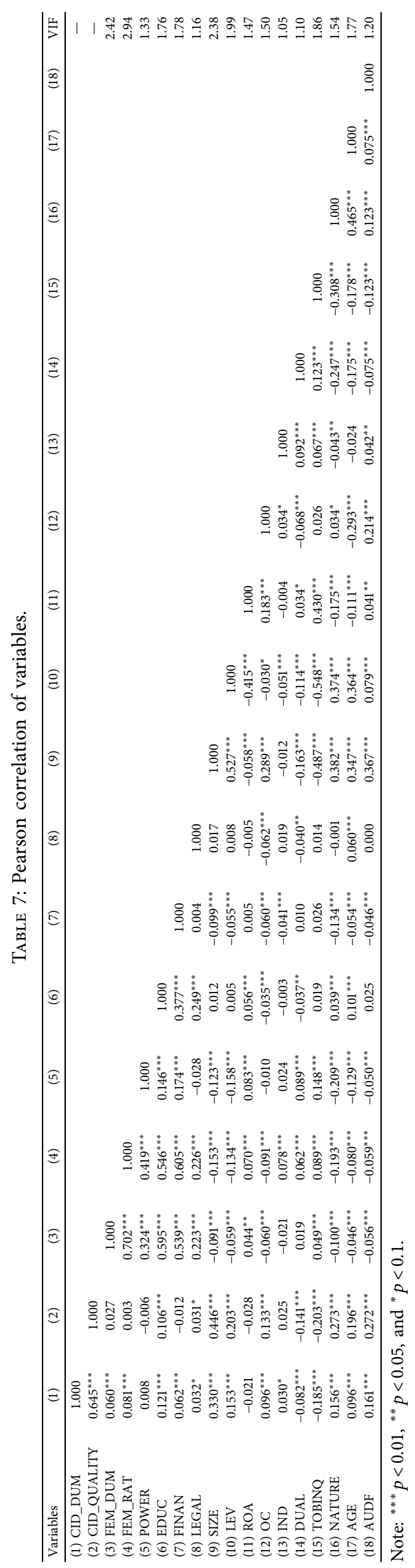


TABLE 8: Regression results of Hypothesis 1.

\begin{tabular}{|c|c|c|c|c|c|c|c|c|}
\hline \multirow{3}{*}{$\begin{array}{l}\text { Variables } \\
\text { FEM_DUM }\end{array}$} & \multicolumn{4}{|c|}{ CID_DUM } & \multicolumn{4}{|c|}{ CID_QUALITY } \\
\hline & \multicolumn{2}{|c|}{ (1) } & \multicolumn{2}{|c|}{$(2)$} & \multicolumn{2}{|c|}{ (3) } & \multicolumn{2}{|c|}{$(4)$} \\
\hline & $0.310^{* * *}$ & $(5.76)$ & & & $0.337^{* * *}$ & $(4.53)$ & & \\
\hline FEM_RAT & & & $1.624^{* * *}$ & $(7.99)$ & & & $1.565^{* * *}$ & $(5.53)$ \\
\hline SIZE & $0.380^{* * *}$ & $(11.18)$ & $0.385^{* * *}$ & $(11.32)$ & $0.708^{* * *}$ & $(15.84)$ & $0.712^{* * *}$ & $(15.95)$ \\
\hline LEV & $-0.556^{* *}$ & $(-3.16)$ & $-0.514^{* * *}$ & $(-2.91)$ & $-1.041^{* * *}$ & $(-4.29)$ & $-1.000^{* * *}$ & $(-4.12)$ \\
\hline ROA & -0.003 & $(-0.55)$ & -0.004 & $(-0.72)$ & $-0.018^{* *}$ & $(-2.18)$ & $-0.019^{* *}$ & $(-2.29)$ \\
\hline $\mathrm{OC}$ & -0.160 & $(-0.83)$ & -0.100 & $(-0.51)$ & -0.155 & $(-0.57)$ & -0.094 & $(-0.34)$ \\
\hline IND & $0.931^{*}$ & $(1.95)$ & 0.644 & $(1.34)$ & $1.570^{* *}$ & $(2.37)$ & $1.300^{*}$ & $(1.96)$ \\
\hline DUAL & -0.035 & $(-0.61)$ & -0.038 & $(-0.64)$ & $-0.221^{* * *}$ & $(-2.67)$ & $-0.225^{* * *}$ & $(-2.73)$ \\
\hline TOBINQ & 0.006 & $(0.25)$ & 0.010 & $(0.41)$ & $0.098^{* * *}$ & $(2.98)$ & $0.102^{* * *}$ & $(3.11)$ \\
\hline NATURE & $0.202^{* * *}$ & $(3.33)$ & $0.235^{* * *}$ & $(3.84)$ & $0.496^{* * *}$ & $(5.81)$ & $0.526^{* * *}$ & $(6.15)$ \\
\hline AGE & $-0.148^{* * *}$ & $(-2.79)$ & $-0.146^{* * *}$ & $(-2.74)$ & 0.050 & $(0.68)$ & 0.051 & $(0.70)$ \\
\hline AUDF & $0.402^{* * *}$ & $(3.40)$ & $0.382^{* * *}$ & $(3.25)$ & $1.119^{* * *}$ & $(7.66)$ & $1.107^{* * *}$ & (7.59) \\
\hline Constant & $-8.727^{* * *}$ & $(-11.62)$ & $-8.795^{* * *}$ & $(-11.72)$ & $-15.056^{* * *}$ & $(-15.21)$ & $-15.085^{* * *}$ & $(-15.27)$ \\
\hline Year & Yes & & Yes & & Yes & & Yes & \\
\hline Industry & Yes & & Yes & & Yes & & Yes & \\
\hline Observations & 3,220 & & 3,220 & & 3,246 & & 3,246 & \\
\hline Pseudo- $R^{2}$ & 0.130 & & 0.137 & & & & & \\
\hline$R$-squared & & & & & 0.269 & & 0.271 & \\
\hline
\end{tabular}

Note: $z$-statistics are in parentheses in columns (1) and (2). $t$-statistics are in parentheses in columns (3) and (4). ${ }^{* * *} p<0.01,{ }^{* *} p<0.05,{ }^{*} p<0.1$.

TABLE 9: The impact of the characteristics of female directors on firms' CID.

\begin{tabular}{lcc}
\hline Variables & CID_DUM & CID_QUALITY \\
& $(1)$ & $0.365^{* * *}(4.20)$ \\
POWER & $0.172^{* * *}(2.77)$ & $0.355^{* * *}(4.70)$ \\
EDUC & $0.259^{* * *}(4.74)$ & $0.025(0.34)$ \\
FINAN & $0.185^{* * *}(3.45)$ & $-0.053(-0.48)$ \\
LEGAL & $-0.010(-0.13)$ & $0.702^{* * *}(15.73)$ \\
SIZE & $0.384^{* * *}(11.22)$ & $-1.027^{* * *}(-4.25)$ \\
LEV & $-0.552^{* * *}(-3.13)$ & $-0.018^{* *}(-2.24)$ \\
ROA & $-0.004(-0.67)$ & $-0.181(-0.67)$ \\
OC & $-0.183(-0.94)$ & $1.503^{* *}(2.27)$ \\
IND & $0.979^{* *}(2.04)$ & $-0.223^{* * *}(-2.71)$ \\
DUAL & $-0.025(-0.43)$ & $0.094^{* * *}(2.87)$ \\
TOBINQ & $0.007(0.28)$ & $0.507^{* * *}(5.91)$ \\
NATURE & $0.220^{* * *}(3.57)$ & $0.038(0.51)$ \\
AGE & $-0.161^{* * *}(-3.01)$ & $1.094^{* * *}(7.52)$ \\
AUDF & $0.376^{* * *}(3.17)$ & $-14.767^{* * *}(-14.97)$ \\
Constant & $-8.746^{* * *}(-11.59)$ & Yes \\
Year & Yes & Yes \\
Industry & Yes & 3246 \\
Observations & 3220 & 0.277 \\
Pseudo- $R^{2}$ & 0.139 & \\
$R$-squared & &
\end{tabular}

Note: $z$-statistics are in parentheses in column (1). $t$-statistics are in parentheses in column (2). ${ }^{* * *} p<0.01$ and ${ }^{* *} p<0.05$.

model. The results based on fixed effect model are reported in column (1) of Table 10, which shows that female directors have a positive influence on firms' CID quality.

The endogenous relation may also exist when reverse causality exists between firms' CID and female directors. Firms with high quality CID or caring more about environmental issues may be more likely to employ women as board members. Alternatively, female directors may also self-select into environmentally friendly firms due to their characteristics. In our study, this means that current female boardroom representation may be influenced by firms' past
CID quality. Our study controls for the possible reverse causality using the system GMM method. The system GMM model shows the same results in column (2) of Table 10: the effect of female directors on firms' CID quality is significantly positive. Our results are thus robust to controlling for endogeneity.

5.3.2. Alternative Independent Variables. We use two other measurements to estimate female directors, FEM_NUM and INDFEM, respectively. The explanatory variable 
TABLE 10: Regression results of the fixed effect and system GMM models.

\begin{tabular}{|c|c|c|}
\hline Variables & $\begin{array}{c}\text { Fixed effect } \\
\text { CID_QUALITY } \\
(1)\end{array}$ & $\begin{array}{c}\text { System GMM } \\
\text { CID_QUALITY } \\
(2)\end{array}$ \\
\hline Lag CID_QUALITY & & $0.514^{* * *}(7.47)$ \\
\hline FEM_RAT & $1.072^{* * *}(3.44)$ & $2.192^{* * *}(3.84)$ \\
\hline SIZE & $0.169^{*}(1.92)$ & $0.371^{* * *}(6.06)$ \\
\hline LEV & $0.158(0.54)$ & $-0.296(-1.39)$ \\
\hline ROA & $0.006(0.87)$ & $-0.005(-0.78)$ \\
\hline OC & $-0.438(-1.13)$ & $0.027(0.10)$ \\
\hline IND & $1.255^{*}(1.90)$ & $-0.135(-0.23)$ \\
\hline DUAL & $-0.112(-1.38)$ & $-0.074(-1.23)$ \\
\hline TOBINQ & $0.004(0.14)$ & $0.050^{* *}(2.38)$ \\
\hline NATURE & $-0.123(-0.42)$ & $0.288^{* * *}(3.32)$ \\
\hline AGE & $-0.069(-0.39)$ & $0.035(0.59)$ \\
\hline AUDF & $-0.041(-0.13)$ & $0.596^{* * *}(2.89)$ \\
\hline Constant & $-2.644(-1.42)$ & $95.671^{* * *}(2.69)$ \\
\hline Year & Yes & Yes \\
\hline Industry & No & Yes \\
\hline Observations & 3,246 & 2,705 \\
\hline$R$-squared & 0.015 & \\
\hline Arellano-Bond AR (1) ( $z, p$ value) & & $-5.66(p \leq 0.001)$ \\
\hline Arellano-Bond AR (2) ( $z, p$ value $)$ & & $1.63(p=0.104)$ \\
\hline Sargan test (chi-square, $p$ value) & & $122.15(p \leq 0.001)$ \\
\hline Hansen test (chi-square, $p$ value) & & $20.59(p=0.151)$ \\
\hline
\end{tabular}

Note: $t$-statistics are in parentheses. ${ }^{* * *} p<0.01,{ }^{* *} p<0.05$, and ${ }^{*} p<0.1$.

TABLE 11: Regression results of alternative independent variables.

\begin{tabular}{|c|c|c|c|c|}
\hline \multirow{2}{*}{ Variables } & \multicolumn{2}{|c|}{ CID_DUM } & \multicolumn{2}{|c|}{ CID_QUALITY } \\
\hline & (1) & (2) & (3) & (4) \\
\hline FEM_NUM & $0.183^{* * *}(7.87)$ & & $0.193^{* * *}(6.03)$ & \\
\hline INDFEM & & $2.544^{* * *}(8.39)$ & & $1.680^{* * *}(3.97)$ \\
\hline SIZE & $0.376^{* * *}(11.05)$ & $0.395^{* * *}(11.57)$ & $0.703^{* * *}(15.76)$ & $0.716^{* * *}(15.97)$ \\
\hline LEV & $-0.513^{* * *}(-2.91)$ & $-0.564^{* * *}(-3.19)$ & $-0.995^{* * *}(-4.11)$ & $-1.047^{* * *}(-4.31)$ \\
\hline $\mathrm{ROA}$ & $-0.004(-0.69)$ & $-0.005(-0.86)$ & $-0.019^{* *}(-2.28)$ & $-0.019^{* *}(-2.29)$ \\
\hline OC & $-0.095(-0.49)$ & $-0.133(-0.68)$ & $-0.084(-0.31)$ & $-0.143(-0.53)$ \\
\hline IND & $0.991^{* *}(2.07)$ & $0.456(0.95)$ & $1.636^{* *}(2.47)$ & $1.229^{*}(1.84)$ \\
\hline DUAL & $-0.037(-0.62)$ & $-0.024(-0.40)$ & $-0.224^{* * *}(-2.72)$ & $-0.217^{* * *}(-2.63)$ \\
\hline TOBINQ & $0.010(0.41)$ & $0.013(0.53)$ & $0.102^{* * *}(3.12)$ & $0.101^{* * *}(3.08)$ \\
\hline NATURE & $0.222^{* * *}(3.63)$ & $0.198^{* * *}(3.24)$ & $0.516^{* * *}(6.05)$ & $0.489^{* * *}(5.73)$ \\
\hline AGE & $-0.143^{* * *}(-2.70)$ & $-0.156^{* * *}(-2.93)$ & $0.054(0.74)$ & $0.040(0.54)$ \\
\hline AUDF & $0.397^{* * *}(3.36)$ & $0.397^{* * *}(3.38)$ & $1.121^{* * *}(7.69)$ & $1.117^{* * *}(7.64)$ \\
\hline Constant & $-8.704^{* * *}(-11.6)$ & $-8.855^{* * *}(-11.79)$ & $-15.011^{* * *}(-15.22)$ & $-15.002^{* * *}(-15.15)$ \\
\hline Year & Yes & Yes & Yes & Yes \\
\hline Industry & Yes & Yes & Yes & Yes \\
\hline Observations & 3220 & 3220 & 3246 & 3246 \\
\hline Pseudo- $R^{2}$ & 0.137 & 0.139 & & \\
\hline$R$-squared & & & 0.273 & 0.268 \\
\hline
\end{tabular}

Note: $z$-statistics are in parentheses in columns (1) and (2). $t$-statistics are in parentheses in columns (3) and (4). ${ }^{* * *} p<0.01,{ }^{* *} p<0.05$, and ${ }^{*} p<0.1$.

FEM_NUM is calculated as the number of women board members, and INDFEM is calculated as the percentage of female independent directors scaled by the total number of board members. We rerun models (2) and (3) using FEM_NUM and INDFEM as alternative key independent variables. As reported in Table 11, the coefficients of both FEM_NUM and INDFEM are consistently positive and significant. These results indicate that the finding that there is a positive correlation between female directors and firms' CID is robust and credible.

\section{Conclusions}

This study examined the potential effect of female directors on firms' CID based on a sample of listed firms in China's high carbon industries in the period between 2012 and 2017. Two alternative variables were used in this paper to measure female directors and firms' CID. We find that female directors have a significant positive impact on firms' CID. Moreover, the result indicates that there is a trend for listed firms in China to appoint women to the board of directors. 
To some extent, the increase in board gender diversity proves the effectiveness of corporate governance policies.

On the basis of the above research, we further explore the effect of the characteristics of female directors on firms' CID. We find that the power and educational level of female directors have a significant positive impact on firms' CID decisions and CID quality. The financial background of female directors has a significant positive impact on firms' CID decisions, while the legal background of female directors has no significant impact on firms' CID behavior.

Based on the empirical results, we could propose some practical implications. First, the statistical results show that firms that disclose carbon information account for less than half of the total sample. This provides a reference for the future mandatory CID policy issued by the Chinese government. Second, since female directors can promote firms' CID decisions and CID quality, Chinese firms can improve their level of information disclosure related to climate change through appointing more female directors. To achieve the target of peaking carbon emissions before 2030 and reaching carbon neutrality before 2060, Chinese government might establish a mandatory quota system of female directors to improve the climate change governance of firms in China. Third, this study finds that the power, educational level, and financial background of female directors in China have a positive impact on firms' CID. Therefore, Chinese firms should appoint more female directors with high level education or financial background to promote firms' CID and appoint female directors as CEO under the same conditions to promote firms' CID behavior.

As in all empirical studies, our study has several limitations. First, the CID index used in our research may not cover all the information that can fully reflect the quality of CID. Second, our study considers only the association between female directors and CID. Future research would benefit from exploring the black box of governance and examining the channels through which female directors positively affect CID. Third, our study focuses on a sample of high carbon industries in China. Therefore, our results may not hold for firms in other industries or firms outside China. The role and influences of female directors may vary across countries. However, our findings may be applied to other Asian countries where the social status of females may be relatively lower than that in western countries, which inspires further discussion and testing by scholars.

\section{Data Availability}

The data used to support this study are available from the corresponding author upon request.

\section{Conflicts of Interest}

The authors declare that there are no conflicts of interest regarding the publication of this study.

\section{Acknowledgments}

This research was funded by Liaoning Provincial Social Science Foundation (Grant no. L19BJY008).

\section{References}

[1] W. Zhang, M. Zhang, W. Zhang, Q. Zhou, and X. Zhang, "What influences the effectiveness of green logistics policies? A grounded theory analysis," The Science of the Total Environment, vol. 714, Article ID 136731, 2020.

[2] J. Peng, J. Sun, and R. Luo, "Corporate voluntary carbon information disclosure: evidence from China's listed companies," The World Economy, vol. 38, no. 1, pp. 91-109, 2015.

[3] C. Dawkins and J. W. Fraas, "Coming clean: the impact of environmental performance and visibility on corporate climate change disclosure," Journal of Business Ethics, vol. 100, no. 2, pp. 303-322, 2011.

[4] D. Li, M. Huang, S. Ren, X. Chen, and L. Ning, "Environmental legitimacy, green innovation, and corporate carbon disclosure: evidence from CDP China 100," Journal of Business Ethics, vol. 150, no. 4, pp. 1089-1104, 2018.

[5] F. Faisal, E. D. Andiningtyas, T. Achmad, H. Haryanto, and W. Meiranto, "The content and determinants of greenhouse gas emission disclosure: evidence from Indonesian companies," Corporate Social Responsibility and Environmental Management, vol. 25, no. 6, pp. 1397-1406, 2018.

[6] Y. Tang, M. Sun, W. Ma, and S. Bai, "The external pressure, internal drive and voluntary carbon disclosure in China," Emerging Markets Finance and Trade, vol. 56, no. 14, pp. 3367-3382, 2020.

[7] L. Li, Q. Liu, D. Tang, and J. Xiong, "Media reporting, carbon information disclosure, and the cost of equity financing: evidence from China," Environmental Science and Pollution Research, vol. 24, no. 10, pp. 9447-9459, 2017.

[8] M. Freedman and B. Jaggi, "Global warming, commitment to the Kyoto protocol, and accounting disclosures by the largest global public firms from polluting industries," The International Journal of Accounting, vol. 40, no. 3, pp. 215-232, 2005.

[9] C. De Villiers, V. Naiker, and C. J. van Staden, "The effect of board characteristics on firm environmental performance," Journal of Management, vol. 37, no. 6, pp. 1636-1663, 2011.

[10] E. Guenther, T. Gunther, F. Schiemann, and G. Weber, "Stakeholder relevance for reporting: explanatory factors of carbon disclosure," Business \& Society, vol. 55, no. 3, pp. 361-397, 2014.

[11] D. Kouloukoui, Â. M. O. Sant'Anna, S. M. da Silva Gomes et al., "Factors influencing the level of environmental disclosures in sustainability reports: case of climate risk disclosure by Brazilian companies," Corporate Social Responsibility and Environmental Management, vol. 26, no. 4, pp. 791-804, 2019.

[12] W. Ben-Amar and P. McIlkenny, "Board effectiveness and the voluntary disclosure of climate change information," Business Strategy and the Environment, vol. 24, no. 8, pp. 704-719, 2015.

[13] L. Liao, L. Luo, and Q. Tang, "Gender diversity, board independence, environmental committee and greenhouse gas disclosure," The British Accounting Review, vol. 47, no. 4, pp. 409-424, 2015.

[14] S. Berthelot and A. M. Robert, "Climate change disclosures: an examination of Canadian oil and gas firms," Issues in Social and Environmental Accounting, vol. 5, no. 1/2, pp. 106-123, 2011.

[15] B. Jaggi, A. Allini, R. Macchioni, and C. Zagaria, "The factors motivating voluntary disclosure of carbon information: evidence based on Italian listed companies," Organization \& Environment, vol. 31, no. 2, pp. 178-202, 2018. 
[16] J. Hollindale, P. Kent, J. Routledge, and L. Chapple, "Women on boards and greenhouse gas emission disclosures," Accounting and Finance, vol. 59, no. 1, pp. 277-308, 2019.

[17] J. Grauel and D. Gotthardt, "The relevance of national contexts for carbon disclosure decisions of stock-listed companies: a multilevel analysis," Journal of Cleaner Production, vol. 133, pp. 1204-1217, 2016.

[18] R. He, M. Zhou, J. Liu, and Q. Yang, "The influence of academic independent directors and Confucianism on carbon information disclosure: evidence from China," Complexity, vol. 2021, Article ID 6646345, 14 pages, 2021.

[19] S. Bear, N. Rahman, and C. Post, "The impact of board diversity and gender composition on corporate social responsibility and firm reputation," Journal of Business Ethics, vol. 97, no. 2, pp. 207-221, 2010.

[20] R. Manita, M. G. Bruna, R. Dang, and L. H. Houanti, "Board gender diversity and ESG disclosure: evidence from the USA," Journal of Applied Accounting Research, vol. 19, no. 2, pp. 206-224, 2018.

[21] M. Kilic and C. Kuzey, "The effect of corporate governance on carbon emission disclosures: evidence from Turkey," International Journal of Climate Change Strategies and Management, vol. 11, no. 1, pp. 35-53, 2019.

[22] W. Zheng, "Maoism, feminism, and the UN conference on women: women's studies research in contemporary China," Journal of Women's History, vol. 8, no. 4, pp. 126-152, 1997.

[23] X. Du, "Does Confucianism reduce board gender diversity? firm-level evidence from China," Journal of Business Ethics, vol. 136, no. 2, pp. 399-436, 2016.

[24] L. Luo, Y.-C. Lan, and Q. Tang, "Corporate incentives to disclose carbon information: evidence from the CDP global 500 report," Journal of International Financial Management \& Accounting, vol. 23, no. 2, pp. 93-120, 2012.

[25] D. C. Matisoff, D. S. Noonan, and J. J. O’Brien, "Convergence in environmental reporting: assessing the carbon disclosure project," Business Strategy and the Environment, vol. 22, no. 5, pp. 285-305, 2013.

[26] B. Bae Choi, D. Lee, and J. Psaros, "An analysis of Australian company carbon emission disclosures," Pacific Accounting Review, vol. 25, no. 1, pp. 58-79, 2013.

[27] A. Kolk, D. Levy, and J. Pinkse, "Corporate responses in an emerging climate regime: the institutionalization and commensuration of carbon disclosure," European Accounting Review, vol. 17, no. 4, pp. 719-745, 2008.

[28] E. M. Matsumura, R. Prakash, and S. C. Vera-Munoz, "Firmvalue effects of carbon emissions and carbon disclosures," The Accouting Review, vol. 89, no. 2, pp. 695-724, 2011.

[29] R. Simnett, M. Nugent, and A. L. Huggins, "Developing an international assurance standard on greenhouse gas statements," Accounting Horizons, vol. 23, no. 4, pp. 347-363, 2009.

[30] B. O'Dwyer, J. Unerman, and E. Hession, "User needs in sustainability reporting: perspectives of stakeholders in Ireland," European Accounting Review, vol. 14, no. 4, pp. 759-787, 2005.

[31] P. Kumar and A. Zattoni, "Corporate governance, board of directors, and the firm: a maturing field," Corporate Governance: An International Review, vol. 22, no. 5, pp. 365-366, 2014.

[32] R. B. Adams and D. Ferreira, "Women in the boardroom and their impact on governance and performance," Journal of Financial Economics, vol. 94, no. 2, pp. 291-309, 2009.
[33] L. A. A. Van den Berghe and A. Levrau, "Evaluating boards of directors: what constitutes a good corporate board?," Corporate Governance, vol. 12, no. 4, pp. 461-478, 2004.

[34] A. J. Hillman, C. Shropshire, and A. A. Cannella, "Organizational predictors of women on corporate boards," Academy of Management Journal, vol. 50, no. 4, pp. 941-952, 2007.

[35] J.-M. Prado-Lorenzo and I.-M. Garcia-Sanchez, "The role of the board of directors in disseminating relevant information on greenhouse gases," Journal of Business Ethics, vol. 97, no. 3, pp. 391-424, 2010.

[36] H. Kang, M. Cheng, and S. J. Gray, "Corporate governance and board composition: diversity and independence of Australian boards," Corporate Governance: An International Review, vol. 15, no. 2, pp. 194-207, 2007.

[37] C. Post and K. Byron, "Women on boards and firm financial performance: a meta-analysis," Academy of Management Journal, vol. 58, no. 5, pp. 1546-1571, 2015.

[38] H. Isidro and M. Sobral, "The effects of women on corporate boards on firm value, financial performance, and ethical and social compliance," Journal of Business Ethics, vol. 132, no. 1, pp. 1-19, 2015.

[39] D. Kim and L. T. Starks, "Gender diversity on corporate boards: do women contribute unique skills?," The American Economic Review, vol. 106, no. 5, pp. 267-271, 2016.

[40] N. Reguera-Alvarado, P. De Fuentes, and J. Laffarga, "Does board gender diversity influence financial performance? Evidence from Spain," Journal of Business Ethics, vol. 141, no. 2, pp. 337-350, 2017.

[41] J. Joecks, K. Pull, and K. Vetter, "Gender diversity in the boardroom and firm performance: what exactly constitutes a "critical mass?,"' Journal of Business Ethics, vol. 118, no. 1, pp. 61-72, 2013.

[42] S. N. Abdullah, K. N. I. K. Ismail, and L. Nachum, "Does having women on boards create value? The impact of societal perceptions and corporate governance in emerging markets," Strategic Management Journal, vol. 37, no. 3, pp. 466-476, 2016.

[43] D. A. Carter, F. D’Souza, W. G. Simkins, and W. G. Simpson, "The gender and ethnic diversity of US boards and board committees and firm financial performance," Corporate Governance: An International Review, vol. 18, no. 5, pp. 396-414, 2010.

[44] H. Al-Shaer and M. Zaman, "Board gender diversity and sustainability reporting quality," Journal of Contemporary Accounting and Economics, vol. 12, no. 3, pp. 210-222, 2016.

[45] L. Cabeza-García, R. Fernández-Gago, and M. Nieto, "Do board gender diversity and director typology impact CSR reporting?," European Management Review, vol. 15, no. 4, pp. 559-575, 2018.

[46] I. Boulouta, "Hidden connections: the link between board gender diversity and corporate social performance," Journal of Business Ethics, vol. 113, no. 2, pp. 185-197, 2013.

[47] P. B. McGuinness, J. P. Vieito, and M. Wang, "The role of board gender and foreign ownership in the CSR performance of Chinese listed firms," Journal of Corporate Finance, vol. 42, pp. 75-99, 2017.

[48] E. E. Landry, R. A. Bernardi, and S. M. Bosco, "Recognition for sustained corporate social responsibility: female directors make a difference," Corporate Social Responsibility and Environmental Management, vol. 23, no. 1, pp. 27-36, 2016.

[49] R. Beji, O. Yousfi, N. Loukil, and A. Omri, "Board diversity and corporate social responsibility: empirical evidence from France," Journal of Business Ethics, 2020. 
[50] C. Francoeur, R. Labelle, S. Balti, and S. EL Bouzaidi, "To what extent do gender diverse boards enhance corporate social performance?," Journal of Business Ethics, vol. 155, no. 2, pp. 343-357, 2019.

[51] C. Post, N. Rahman, and E. Rubow, "Green governance: boards of directors' composition and environmental corporate social responsibility," Business \& Society, vol. 50, no. 1, pp. 189-223, 2011.

[52] L. Chelsea, "Are women greener? Corporate gender diversity and environmental violations," Journal of Corporate Finance, vol. 52, pp. 118-142, 2018.

[53] W. Ben-Amar, M. Chang, and P. McIlkenny, "Board gender diversity and corporate response to sustainability initiatives: evidence from the carbon disclosure project," Journal of Business Ethics, vol. 142, no. 2, pp. 369-383, 2017.

[54] M. C. Jensen and W. H. Meckling, "Theory of the firm: managerial behavior, agency costs and ownership structure," Journal of Financial Economics, vol. 3, no. 4, pp. 305-360, 1976.

[55] M. A. Gulzar, J. Cherian, J. Hwang, Y. Jiang, and M. S. Sial, "The impact of board gender diversity and foreign institutional investors on the corporate social responsibility (CSR) engagement of Chinese listed companies," Sustainability, vol. 11, no. 2, p. 307, 2019.

[56] M. Nekhili, H. Nagati, T. Chtioui, and A. Nekhili, "Genderdiverse board and the relevance of voluntary CSR reporting," International Review of Financial Analysis, vol. 50, pp. 81-100, 2017.

[57] J. Pfeffer and G. R. Salancik, The External Control of Organizations: A Resource Dependence Perspective, Stanford University Press, Palo Alto, CA, USA, 2003.

[58] A. J. Hillman, A. A. Cannella, and R. L. Paetzold, "The resource dependence role of corporate directors: strategic adaptation of board composition in response to environmental change," Journal of Management Studies, vol. 37, no. 2, pp. 235-256, 2000.

[59] D. C. Hambrick and P. A. Mason, "Upper echelons: the organization as a reflection of its top managers," Academy of Management Review, vol. 9, no. 2, pp. 193-206, 1984.

[60] A. H. Eagly, M. C. Johannesen-Schmidt, and M. L. van Engen, "Transformational, transactional, and Laissez-Faire leadership styles: a meta-analysis comparing women and men," Psychological Bulletin, vol. 129, no. 4, pp. 569-591, 2003.

[61] B. S. Coffey and J. Wang, "Board diversity and managerial control as predictors of corporate social performance," Journal of Business Ethics, vol. 17, no. 14, pp. 1595-1603, 1998.

[62] S. Nielsen and M. Huse, "The contribution of women on boards of directors: going beyond the surface," Corporate Governance: An International Review, vol. 18, no. 2, pp. 136-148, 2010.

[63] I. van Staveren, "The Lehman sisters hypothesis," Cambridge Journal of Economics, vol. 38, no. 5, pp. 995-1014, 2014.

[64] M. H. Elmagrhi, C. G. Ntim, A. A. Elamer, and Q. Zhang, “A study of environmental policies and regulations, governance structures, and environmental performance: the role of female directors," Business Strategy and the Environment, vol. 28, no. 1, pp. 206-220, 2019.

[65] M. Huse and A. Grethe Solberg, "Gender-related boardroom dynamics," Women in Management Review, vol. 21, no. 2, pp. 113-130, 2006.

[66] I. Tingbani, L. Chithambo, V. Tauringana, and N. Papanikolaou, "Board gender diversity, environmental committee and greenhouse gas voluntary disclosures,"
Business Strategy and the Environment, vol. 29, no. 6, pp. 2194-2210, 2020.

[67] M. Al-Qahtani and A. Elgharbawy, "The effect of board diversity on disclosure and management of greenhouse gas information: evidence from the United Kingdom," Journal of Enterprise Information Management, vol. 33, no. 6, pp. 1557-1579, 2020.

[68] B. Srinidhi, F. A. Gul, and J. Tsui, "Female directors and earnings quality," Contemporary Accounting Research, vol. 28, no. 5, pp. 1610-1644, 2011.

[69] P. Withisuphakorn and P. Jiraporn, "CEO age and CEO gender: are female CEOs older than their male counterparts?," Finance Research Letters, vol. 22, pp. 129-135, 2017.

[70] Y. Liu, Z. Wei, and F. Xie, "Do women directors improve firm performance in China?," Journal of Corporate Finance, vol. 28, pp. 169-184, 2014.

[71] S. Chen, X. Ni, and J. Y. Tong, "Gender diversity in the boardroom and risk management: a case of R\&D investment," Journal of Business Ethics, vol. 136, no. 3, pp. 599-621, 2016.

[72] M. A. Hitt and B. B. Tyler, "Strategic decision models: integrating different perspectives," Strategic Management Journal, vol. 12, no. 5, pp. 327-351, 1991.

[73] A. Vives, "Social and environmental responsibility in small and medium enterprises in Latin America," The Journal of Corporate Citizenship, vol. 2006, no. 21, pp. 39-50, 2006.

[74] D. L. Gadenne, J. Kennedy, and C. McKeiver, "An empirical study of environmental awareness and practices in SMEs," Journal of Business Ethics, vol. 84, no. 1, pp. 45-63, 2009.

[75] A. Diamantopoulos, B. B. Schlegelmilch, R. R. Sinkovics, and G. M. Bohlen, "Can socio-demographics still play a role in profiling green consumers? a review of the evidence and an empirical investigation," Journal of Business Research, vol. 56, no. 6, pp. 465-480, 2003.

[76] M. J. O'Fallon and K. D. Butterfield, “A review of the empirical ethical decision-making literature: 1996-2003," Journal of Business Ethics, vol. 59, no. 4, pp. 375-413, 2005.

[77] B. J. Sleeper, K. C. Schneider, P. S. Weber, and J. E. Weber, "Scale and study of student attitudes toward business education's role in addressing social issues," Journal of Business Ethics, vol. 68, no. 4, pp. 381-391, 2006.

[78] V. M. Panapanaan, L. Linnanen, M. Karvonen, and V. T. Phan, "Roadmapping corporate social responsibility in finnish companies," Journal of Business Ethics, vol. 44, no. 2-3, pp. 133-148, 2003.

[79] A. Ziegler, T. Busch, and V. H. Hoffmann, "Disclosed corporate responses to climate change and stock performance: an international empirical analysis," Energy Economics, vol. 33, no. 6, pp. 1283-1294, 2011.

[80] T. T. Lemma, M. Feedman, M. Mlilo, and J. D. Park, "Corporate carbon risk, voluntary disclosure, and cost of capital: South African evidence," Business Strategy and the Environment, vol. 28, no. 1, pp. 111-126, 2019.

[81] K. Alsaifi, M. Elnahass, and A. Salama, "Carbon disclosure and financial performance: UK environmental policy," Business Strategy and the Environment, vol. 29, no. 2, pp. 711-726, 2020.

[82] A. A. Gull, M. Nekhili, H. Nagati, and T. Chtioui, "Beyond gender diversity: how specific attributes of female directors affect earnings management," The British Accounting Review, vol. 50, no. 3, pp. 255-274, 2018.

[83] B. W. Lewis, J. L. Walls, and G. W. S. Dowell, "Difference in degrees: CEO characteristics and firm environmental disclosure," Strategic Management Journal, vol. 35, no. 5, pp. 712-722, 2014. 
[84] V. L. Barker and G. C. Mueller, "CEO characteristics and firm R\&D spending," Management Science, vol. 48, no. 6, pp. 782-801, 2002.

[85] L. S. Bamber, J. Jiang, and I. Y. Wang, "What's my style? The influence of top managers on voluntary corporate financial disclosure," The Accounting Review, vol. 85, no. 4, pp. 1131-1162, 2010.

[86] S. Brammer and S. Pavelin, "Factors influencing the quality of corporate environmental disclosure," Business Strategy and the Environment, vol. 17, no. 2, pp. 120-136, 2008.

[87] A. Liesen, A. G. Hoepner, D. M. Patten, and F. Figge, "Does stakeholder pressure influence corporate GHG emissions reporting? empirical evidence from Europe," Accounting, Auditing \& Accountability Journal, vol. 28, no. 7, pp. 10471074, 2015.

[88] W. Qian, J. Hörisch, and S. Schaltegger, "Environmental management accounting and its effects on carbon management and disclosure quality," Journal of Cleaner Production, vol. 174, pp. 1608-1619, 2018.

[89] C. J. P. Chen and B. Jaggi, "Association between independent non-executive directors, family control and financial disclosures in Hong Kong," Journal of Accounting and Public Policy, vol. 19, no. 4, pp. 285-310, 2000.

[90] K. A. Dunn and B. W. Mayhew, "Audit firm industry specialization and client disclosure quality," Review of Accounting Studies, vol. 9, no. 1, pp. 35-58, 2004. 